\title{
Comparison of Antimicrobial Properties and Toxicity of Natural S3 Peptide with Horseshoe Crab Amoebocyte Origin and its Mutants
}

\author{
Sadegh Rezaei $^{1}$, Sahin Hadadian ${ }^{2 *}$, Ramazan Ali Khavarinejad $^{1}$, Dariush Norouzian ${ }^{2}$ \\ ${ }^{1}$ Dept of Biology, Islamic Azad University, Science and Research Branch, Tehran, Iran \\ ${ }^{2}$ Dept of Nanotechnology, New Technologies Research Group, Pasteur Institute of Iran, Tehran, Iran
}

$$
\text { Article Info }
$$

Article type:

Research article

\section{Article History:}

Received: 19 May 2021

Revised: 07 June 2021

Accepted: 01 September 2021

\section{* Correspondence to: \\ Shahin Hadadian \\ Dept of Nanotechnology, New \\ Technologies Research Group, \\ Pasteur Institute of Iran, Tehran, \\ Iran \\ Email: hadadian@yahoo.com}

\author{
A B S T R A C T
}

Introduction: Antimicrobial peptides (AMPs) are compounds with antimicrobial properties that are studied widely due to the development of resistance of pathogenic bacteria to antibiotics. In the present study, the toxicity and antimicrobial effects of two natural monomeric peptides ( $\mathrm{S} 3$ and $\mathrm{S} \Delta 3$ ) were compared with $\mathrm{S} 3-\mathrm{S} \Delta 3$ hybrids and $\mathrm{S} 3$ tetramers.

Material \& Methods: Protein hybrids (S $\Delta 3 \mathrm{~S} 3-2$ mer-GS) S3-S $\Delta 3$ and tetramer protein S3 (S3-4mer-GS) were expressed in E. coli. BL21 (DE3). Following that, the presence of mutant peptides was confirmed, and their antimicrobial activity was compared and evaluated with $\mathrm{S} 3$ and $\mathrm{S} \Delta 3$ monomers. Finally, the toxicity of tetramer and hybrid made on the MDA-MB-231 cell line was evaluated and compared.

Findings: The toxicity of the hybrid was slightly increased, compared to the tetramer for eukaryotic cells; however, this increase was negligible at the active concentration of this protein. Cell survival for hybrids was lower for $\mathrm{S} 3$ and $\mathrm{S} \Delta 3$; nonetheless, cell survival for each sequence decreased with increasing time. Furthermore, the inhibition of hybrid microbial growth was improved and compared with tetramer and $\mathrm{S} 3-\mathrm{S} \Delta 3$. It was found that an increase in the positive charge of the hybrid protein did not have a toxic effect on the host bacteria.

Discussion \& Conclusion: Due to the appropriate expression and increased antimicrobial activity and negligible cytotoxicity, the hybrid peptide $\mathrm{S} 3-\mathrm{S} \Delta 3$ and tetramer S3 can be considered an effective production strategy to obtain AMPs.

Keywords: Antimicrobial peptides, Factor c, Horseshoe crab, S3-S $\Delta 3$ protein hybrid, Tetramer S3 peptide

\footnotetext{
$>$ How to cite this paper
}

Rezaei S, Hadadian Sh, Khavarinejad RA, Norouzian D. Comparison of Antimicrobial Properties and Toxicity of Natural S3 Peptide with Horseshoe Crab Amoebocyte Origin and its Mutants. Journal of Ilam University of Medical Sciences. November 2021;29(4): 60-73. 


\section{مقايسؤ خاصيت ضدميكروبى و سميت ِِيتيد S3 طبيعى با منشأ خر جنكَ نعلاسبى، با موتانت هاى حاصل از آن}

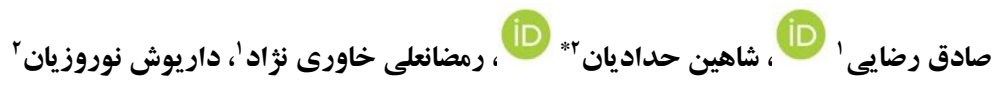
اكروه زيستشناسى، دانشخاه آزاد اسلامى، واحد علوم و تحقيقات، تهران، ايران

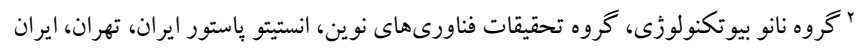

اطلاعات مقاله

مقدمه: ييتيدهاى ضدميكروبى (AMP) تركياتى با خاصيت ضدميكروبى هستند كه به سبب ظهور مقاومت باكترىهاى نوع مقاله: يُزوهشى

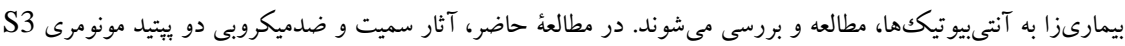

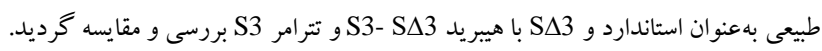

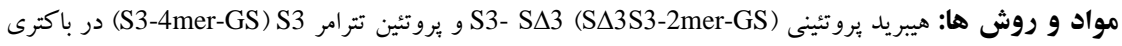
و S3.coli. BL21 (DE3) مطالعه كرديد. درنهايت، سميت تترامر و هيبريد ساخته شده روى ردؤ سلولى SA3

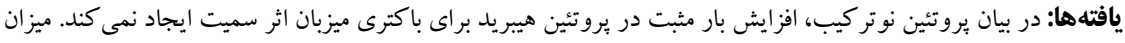

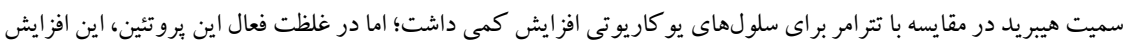

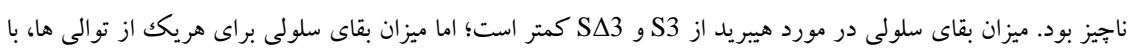

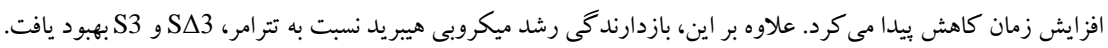
بحث و نتيجه كيرى: با توجه به ميزان بيان مناسب و افزايش فعاليت ضدميكروبى و سميت سلولى اندك، ييتيد هيبريد S3

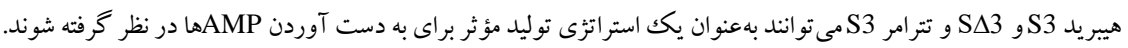

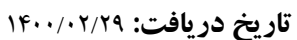

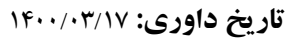

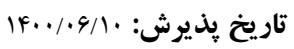

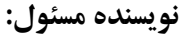
شاهين حداديان كروه نانو بيوتكنولوزى، خروان تحقيقات فناورىهاى نوين، انستيتو

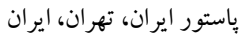

Email:

hadadian@yahoo.com

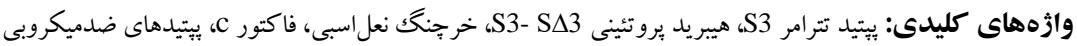

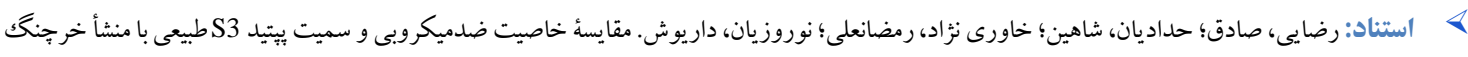

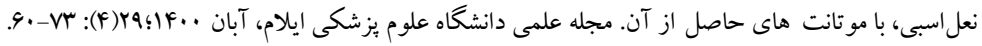


مشابهى در تخريب غشاى اين نوع سلولها داشته باشند

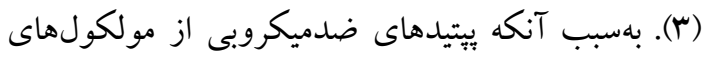
مهم ايمنى ذاتى بدن هستند و سميت سلولى اندكى دارند،

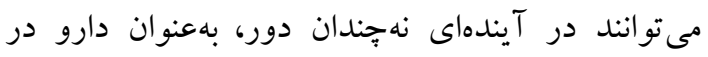

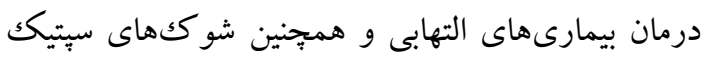
حاصل از اندوتو كسين باكترىها استفاده شوند. يتيتيدهاى

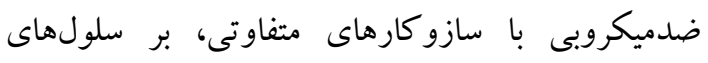

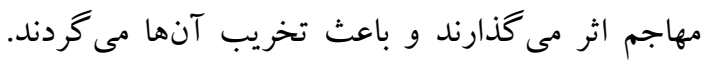

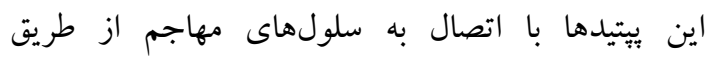

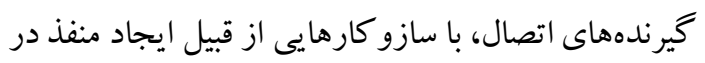

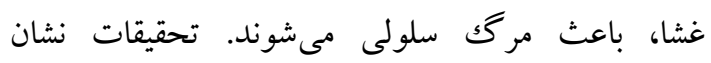
مىدهند كه با افزايش درصد اتصال ييتيد به سلول، آثار يبتيد افزايش مىيابد؛ بنابراين، تيمار سلولها با غلظتهاى كوناگون يِيتيد براى بررسى تغييرات اتصالى و و آثار

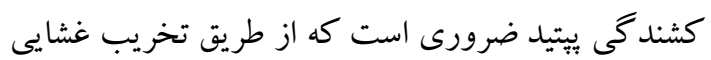
و يا تخريبهاى درونسلولى اعمال مىشوند (F). بهاطور كلى سنتز يَيتيدها، فرايند بِيجِيده، يرهزينه و زمانبرى

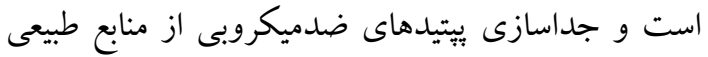
آنها نيز علاوه بر زمانبر و برهزينه بودن، در بسيارى موارد، با حفظ تعادل اكوسيستم در تضاد خواهد بود (ه). اين يّيتيدها اغلب آمينواسيدهاى تغييرشكل يافته و اصلاحشدهاى دارند كه با بروتئينهاى ساختهشده توسط ريبوزومها متفاوتاند. در حال حاضر، روشهاى توليد نوتركيب به سبب بيان بروتئينى اندك و حساسيت به يروتئزازهاى مو جود در محيط، مناسب نيست و امروزه، بيان

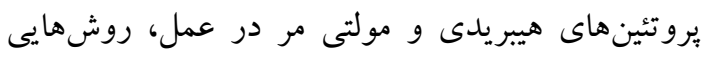

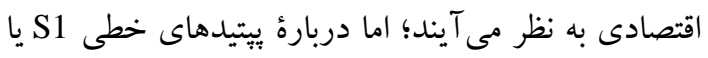

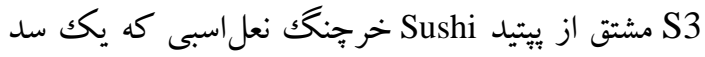
دفاعى طبيعى در اين جاندار در برابر تهاجم باكترىهاى

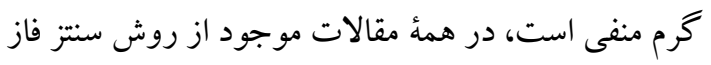

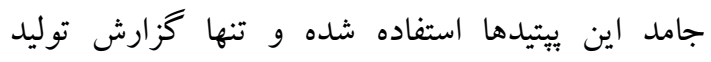
نوتركيب آنها، مربوط به بيان مولتىمر S3 در ميزبان E.coli BL21 (DE3)
ظهور مقاومت آنتىبيوتيكى به يك يا جند آنتىبيو تيكك و افزايش مقاومت دارويى باكترىها به درمان با نسل هاى مختلف داروها و آنتىبيو تيك ها كه حاصل آن افزايش مر گكومير و بروز آثار جانبى داروهاى موجود شده است، ضرورت مطالعه و توليد داروهاى آنتى ميكروبيال

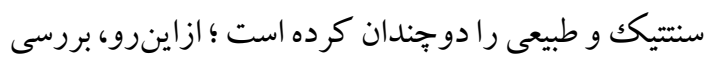

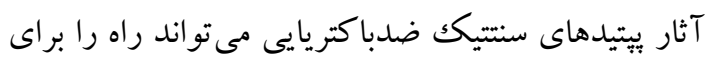
به دست آوردن آنتىيوتيككهاى جديد هموار سازد.

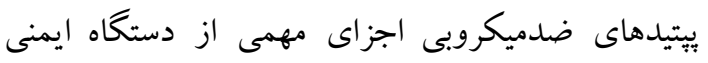

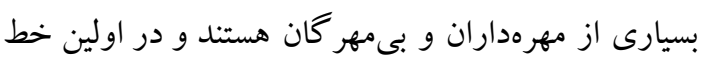
دفاعى ميزبان بر ضد تهاجم ميكروار كانيسمها حضور دارند. سميت اين يبتيدها به علت ظرفيت مداخله كر آنها

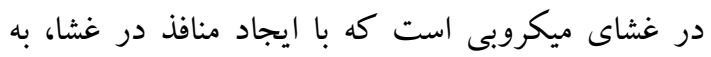

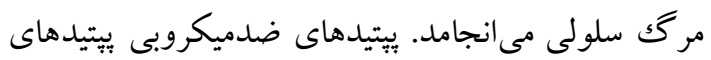
كوجِكى هستند كه به سبب حضور ليزين و يا آرزنين در توالى خود، بار مثبت دارند و آمفىياتيك هستند سئد

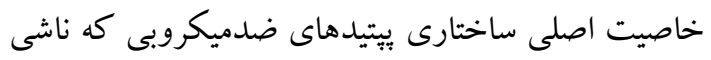

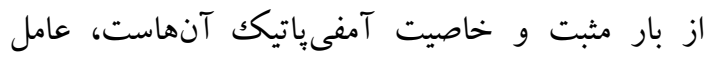

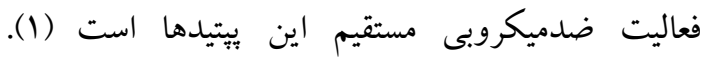
يتيدهاى ضدميكروبى دو ويزگ گیى جذاب دارند: اول اينكه فعاليت ضدميكروبى آنها عليه طيف وسيعى از باكترىها است؛ ويزگى دوم، هدف قرار دادن غشاهاى ميكروبى

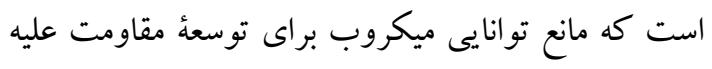
آنها مىشود (Y)؛ درنتيجه، اين ييتيدها بهواسطة قابليت كاربرد آنها، بهعنوان آنتى بيو تيككهاى نسل جديد، منفعت بسيار دارند. سازو كار فعاليت يّتيدهاى ضدميكروبى، توانايى آنها در تخريب غشاى سلولى است. يِيتيدهاى

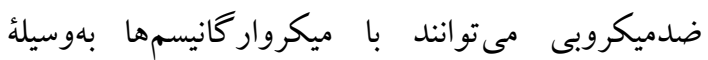
نيروهاى الكترواستاتيك، ميان اسيدهاى آمينه مثبت خود با اسيدهاى آمينٔة منفى روى سطح ميكرواركانيسمها

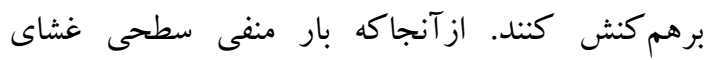

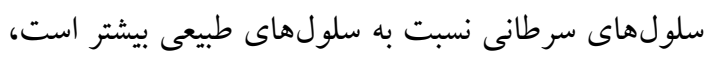
به نظر مىرسد كه يتيدهاى ضدميكروبى سازوكار 
سفارش داده شد. سازه هاى زنى در و كتور (+) pET-26b)

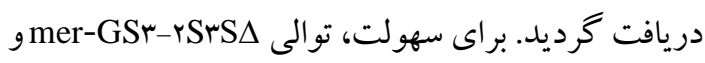
mer-GSr-FS

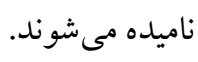

تكثير ٍِاسميد، تخليص و تهيئ سلولهاى مستعل:

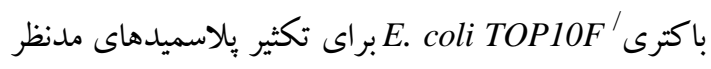

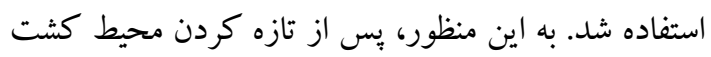
اين باكترى، وكتورهاى طر احىشدهُ حاوى زن هاى مدنظر

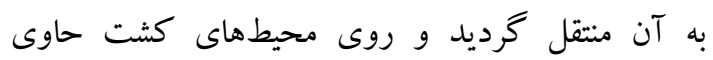
آنتى بيوتيكك هاى كانامايسين و تتراسايكلين كه موجب رشد وشد اختصاصى سويههاى داراى بِلاسميد فوق است، كشت داده شد. بس از انتقال وكتورها به ميزبان 'E. Coli TOP10F فرايند تخليص بِلاسميد با استفاده از كيت تخليص بِلاسميد Qiagen extraction kit (Germany) نمونه ها براى مشاهدة كيفيت عمل استخراج، روى زل آكارز ا درصد (Agarose RPI) برده شدند. براى انتقال سازهؤ زنى به سلولهاى E. Coli لازم است كه با استفاده از لركائ تيمارهاى خارجى، سلول باكترى را آماده كرد. از استوك لك

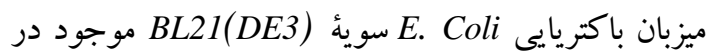
فريزر منفى •V درجه، ·ل ميكروليتر برداشته و با لوبٍ شيشهاى روى بليت حاوى LB(LB agar Thermo Fisher)

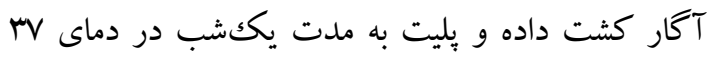

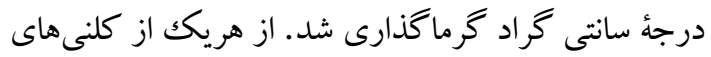
رشديافته بر يليتهاى بالا، يك كلنى برداشته و در ه ميلى ليتر از محيط كشت Lisher) تلقيح گرديد و در شيكر انكوباتور با دماى WV درجئ

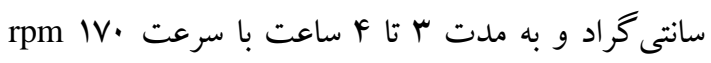
كشت داده شد. هنكامى كه جذب نورى سلولها

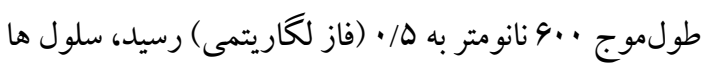
به كمكك سانتريفوز در دور

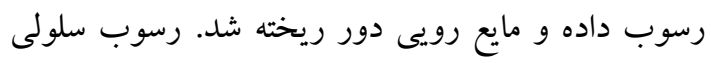

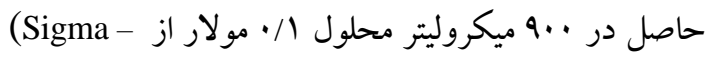
سرد حل كرديد و به مدت ·r دقيقه روى $\mathrm{CaCl}_{2}$ Aldrich) يخ قرار گرفت. سلولها در دور

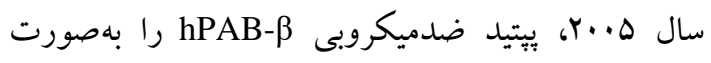
مولتىمر در E.coli BL21(DE3) بيان كردند و دريافتند كه مانس

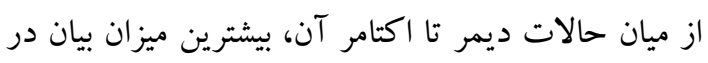

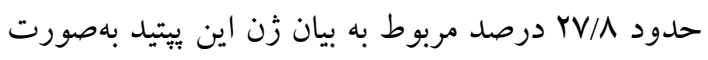

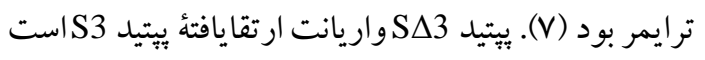

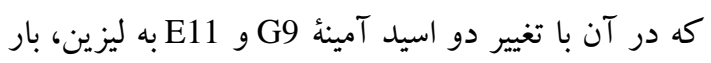

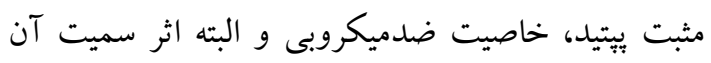

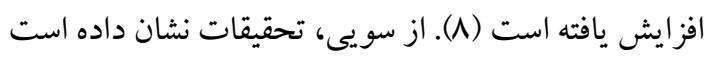

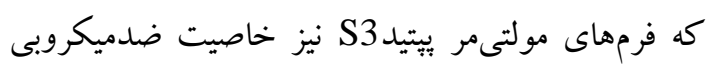

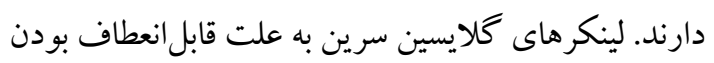
و كاهش ممانعت فضايى اجزاى متصل شده، باعث افزايش

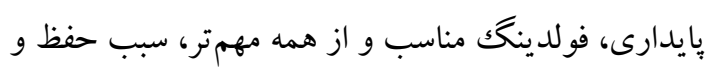
حتى افزايش فعاليت بيولوزيكى قطعات بروتئينى متصل

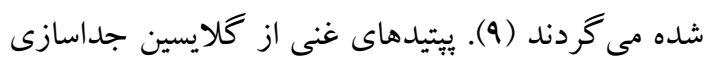

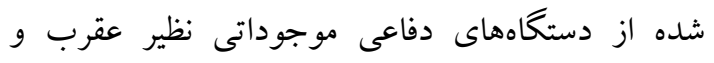

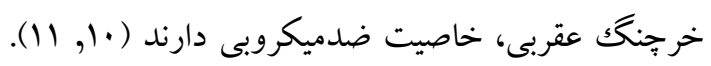
ابتدا توالى هريك از سكانس ها با افزودن لينكر مدنظر، His tag و سايت انترو كينازى مشخص شد. در اين مطالعه، توالى يبتيدهاى مدنظر شامل يك توالى تترامر هيبريدى S3

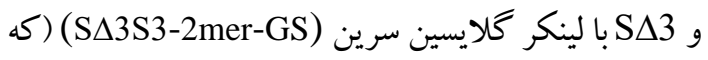

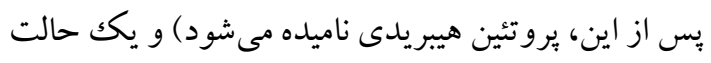
تترامر يّيتيد S3 با لينكر كلايسين سرين (S3-4mer-GS)

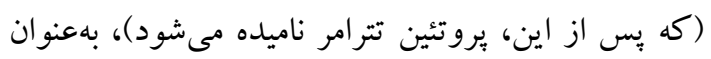

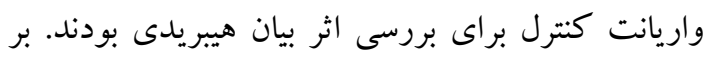

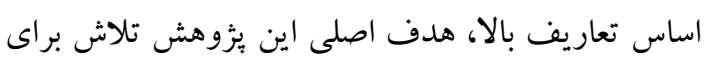

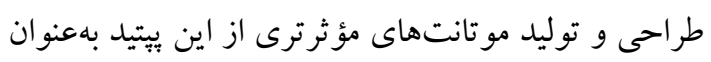
ييتيدهاى ضدميكروبى است.

\section{مواد و روش ها}

سنتز ثن: براى تعيين توالى DNA، تو الىهاى بروتئينى طراحىشده از ترجمة معكوس سايت ExPASy استفاده شد. سايتهاى برشى NdeI و XhoI به انتهاى 'S ', '5 آن و دنبالة هيستيدنى و همجينين سايت برش انترو كيناز به آن

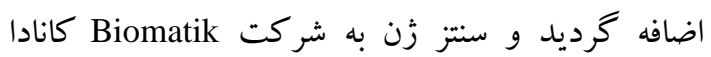


دقيقه در دماى F درجه با همزن مغناطيسى همزده شد.

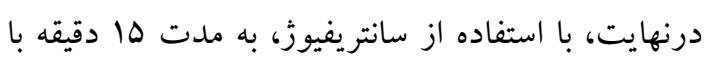
سرعت rpm . . .9، مايع رويى حاوى يروتئين حل شده جمع آورى گرديد (19).

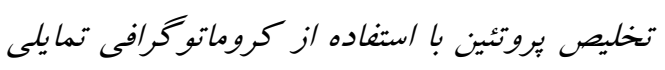
يون فلزى(IMAC). براى تخليص هريك از توالى ها، NiNTA (Agarose Bead يك ميلى يتر تركين (ml Y) Technologies-ABT) HiTrap® (SP Fast Flow Cytiva Hitrap) درون ستون يكك ميلى ليترى ريخته شد و يس از متعادل سازى با ه ميلى ليتر بافر متعادلسازى با شدت جريان اml/min، نمونه به

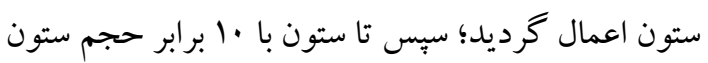
از بافر متعادلسازى تا رسيدن جذب A280 به 0.01> و يس از آن، با F برابر حجم ستون از بافر شستشو داده شد؛

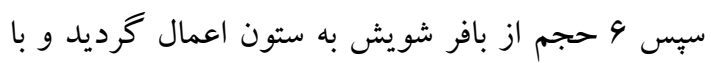
مشاهده بيكك، فركشن هاى يكك ميلىليترى مربوط به مشاهده بيكك جمع آورى شدند (V9). درنهايت، ستون با استفاده از ه حجم محلول بازيابى براى استفادهُ مجدد شستشو داده و با عبور دادن اتانول ·r درصد (دو حجم ستون) تا استفاده بعدى در يخجال نگهدارى گرديد. حضور يِيتيد هدف در نمونهُ شويش (جداسازى شده از ستون) با استفاده از SDS-PAGE تأيد شد (19). غلظت يروتئينهاى تخليص شده با استفاده از اندازه گيرى جذب

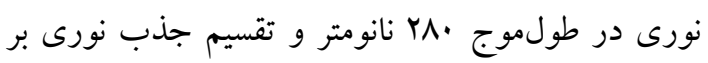
ضريب خاموشى // • درصد آنها محاسبه گرديد. ضريب خاموشى بروتئينهاى تترامر و هيبريد با استفاده از توالى آلى اسيد آمينههاى آنها و با استفاده از تخمين خو اص فيزيكى ليكى شيميايى آنها در سايت ExPASy به ترتيب معادل سMAM/.

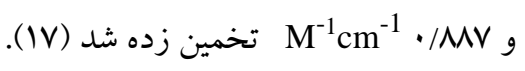

وسترن بلاتينگ (Western Blotting). يرو تئينهايى كه در مرحلهُ بيش، در زل SDS-PAGE از نظر اندازه از يكديخر جداشده بودند، با استفاده از ولتاز الكتريكى به روى درى درل كاغذ نيتروسلولز منتقل گرديدند. كاغذ نيتروسلولز ظرفيت بسيار مناسبى (در حدود V.
سانتريفوز شدند. رسوب سلولى در . .9 ميكروليتر محلول / • مولار از CaCl2 سرد حل گرديد و به مدت •ب دقيقه روى يخ قرار گرفت. سلولها دوباره در دور مدت r دقيقه سانتريفوز شدند. رسوب سلولى در مرن ميكروليتر محلول // • مولار از مaCl $\mathrm{CaCl}_{2}$ سرد حل گرديد (19). ترانسفورماسيون باكترى BL21 با وكتور نوتركيب: يس از آماده شدن سلولهاى مستعد، سازهُ زنى بهمنظور بيان به باكترى BL coli سوية (DE3 منتقل مى شود. بس از انتقال سازه هاى زنى به سلول هاى بيانى، سلولهاى

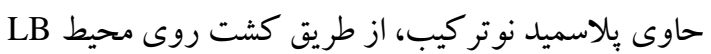

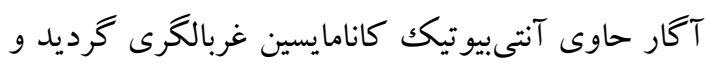
كلنىهاى غربالكرى شده در محيط كشت مايع LB كشت آتى داده شدند. يس از رسيدن كشت باكترى به OD OD 0.6 طولموج · · ،نانومتر، باكترى با افزودن IPTG با غلظت نهايى ه/ • ميلى مولار القا گرديد و دوباره به مدت \& ساعت در شيكر انكوباتور با دماى WV درجة سانتى گراد قرار داده شد (19). مراحل بيان اين بروتئين ها در باكترى با استفاده از آزمون SDS-PAGE و استخراج يروتئين نوتركيب: يس از جداسازى بيومس از محيط كشت بهوسيلة سانتريفيوز، ديواره سلولى از طريق حل كردن بلت ها به نسبت ه: ا وزنى / حجمى در محلول ليز كننده pH=7.5 ميلى مولار ب . tris- HCl Adak shimi) استفاده از دستگاه اولتراسونيك (ده يالس .ب ثانيه توقف •r ثانيه) شكسته شد و يس از شستشو و حذف بقاياى ديواره سلولى شكسته شده، اينكلوزَن بادى ها با استفاده از سانتريفيوز به مدت · لا دقيقه و دور بهصورت يلت جداسازى گرديد و براى شستشو در بافر حاوى اوره r pH=7.5 ميلى مولار ب tris- HCl حل شد و يس از سانتريفيوز بر اساس (Urea Merck)

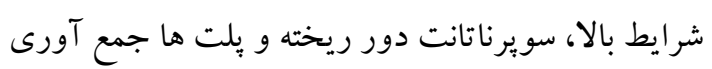
كرديد؛ سيس اينكلوزَن بادى شسته شده با استفاده از بافر

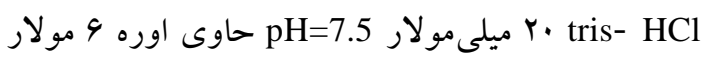

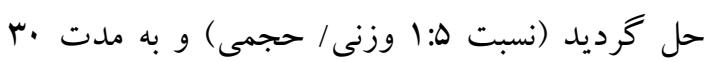


از سرم نمكى سترون تا رسيدن به غلظت سلولى CFU/ml ه × ه مقيق شد (حصول كدورت مشابه كدورت

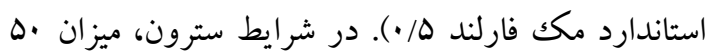

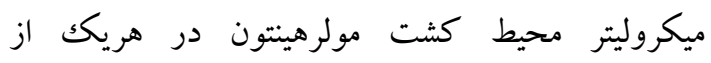

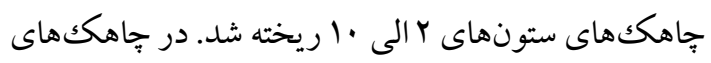

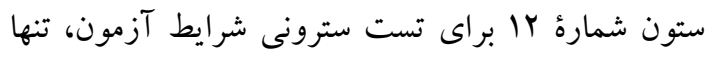

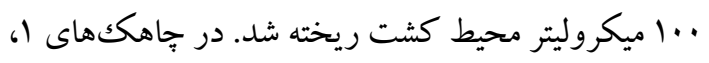

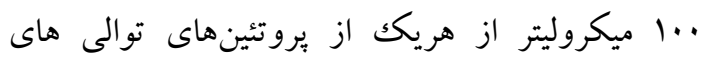

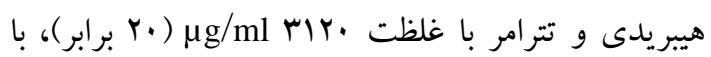
استفاده از محيط كشت مولر هينتون · ا برابر رقيق كرديد و به غلظت بو ر رسانده شد (غلظت نهايى دو

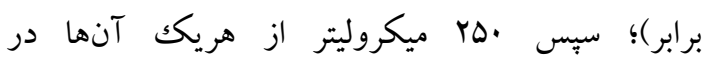

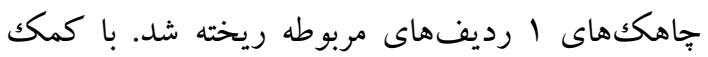

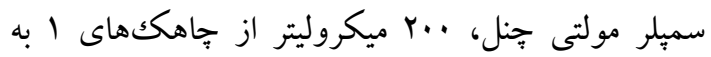

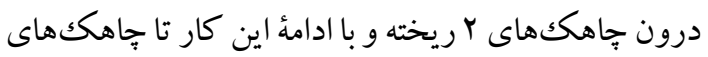

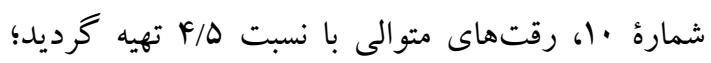

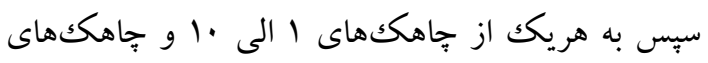

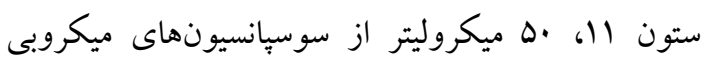

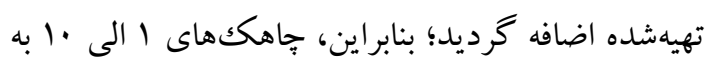

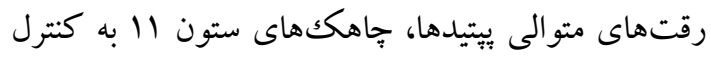

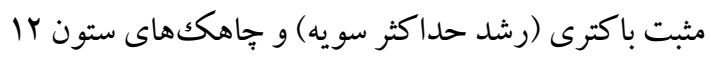
به كنترل منفى باكترى (تست سترونى آزمون) اختصاص

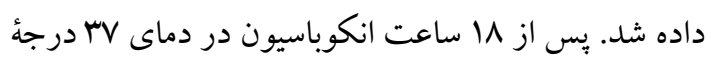

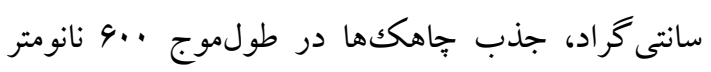
قرائت شد و حداقل غلظتى از يروتئين كه جذب آن آن معادل هو درصد جذب سلول فاقد يروتئين بود، بهعنوان حداقل

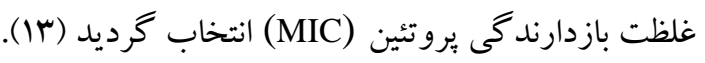

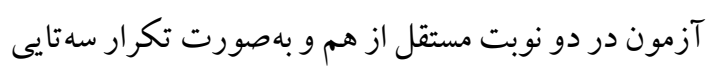

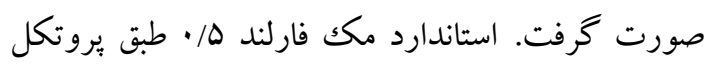

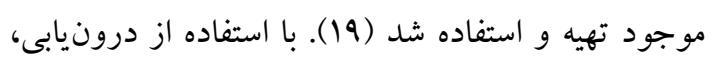
مقادير MIC براى همدٔ تكرارها تعيين گرديد و آناليزهاى آمارى روى اين مقادير انجام شد. از منحنى Box- Plot

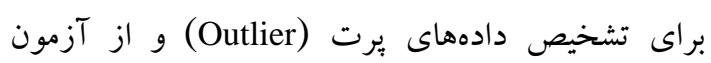

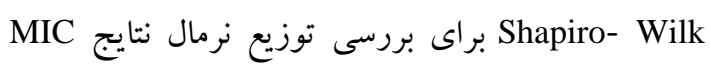

Semi (bio rad) نشان مىدهد. در اين تحقيق، از دستكاه

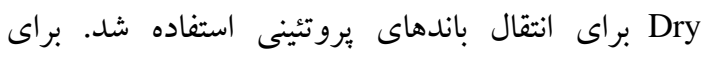

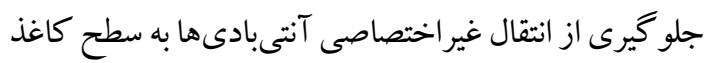

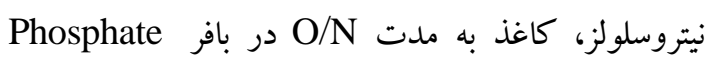
Bovine حاوى buffered saline (PBS Gibco) قرار

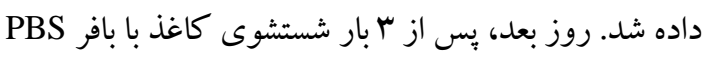
حاوى ه•/ \% Tween RPI) Tween20)، آنتىبادى عليه دنبالة هيستيدينى متصل به آنزيم براكسيداز، با رقت البه

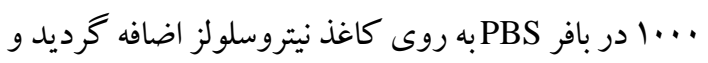
به مدت r ساعت در دماى اتاق روى شيكر قرار داده شد. پس از شستشوى مجدد كاغذ با بافر شستشو،

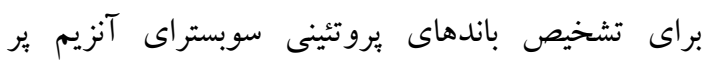
اكسيداز Diaminobenzidine (DAB Thermo Fisher) tetrahydrochloride (DAB)

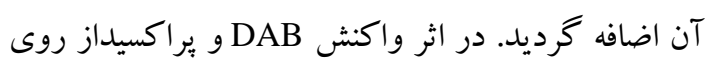

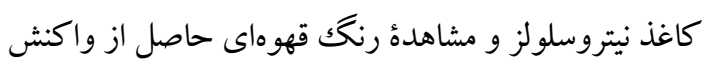

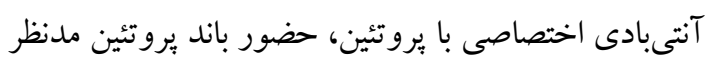
تأييد شد (19,11)

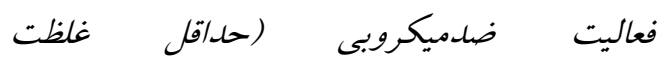

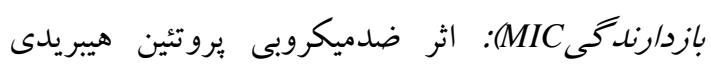

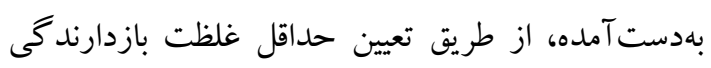

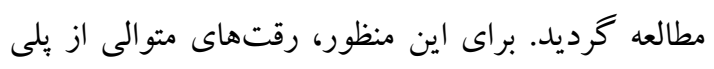

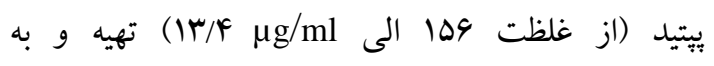

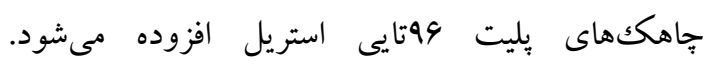
pseudomonas aeruginosa باكترىهاى گرم منفى مختلف سوية استاندارد ATTC27853 و سوية كلينيكى مقاوم ايزولهشده در كلينيك طوس و Escherichia coli سوئ

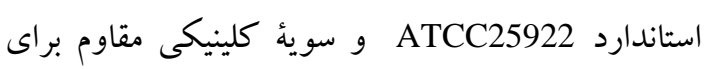
مطالعه اثر يّتيد آنتىميكروبيال بر سويةٔ استاندارد و مقاوم

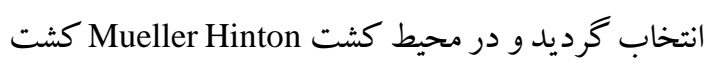
شبانه داده شد و سبس با افزودن ... ميكروليتر از كشت

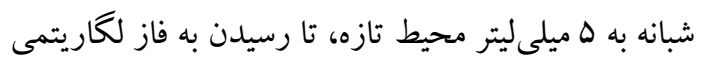
كشت گرديد؛ يس از آن، با استفاده (OD 600nm 0.6) 
كشت آماده مطابق بالا) به ميزان ..1 ميكروليتر به هر

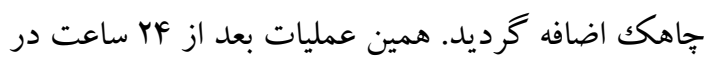
ميكرويليت هاى جديد تكرار شدو به اين ترتيب، سلو لهاى

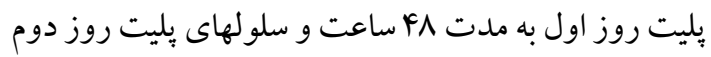

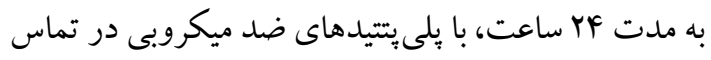

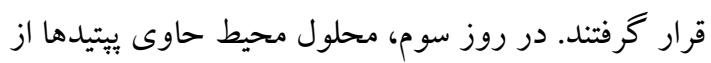

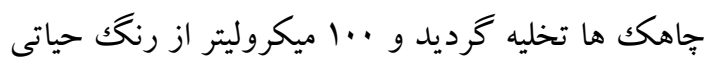
formazonMTT با غلظت شد و بِ از F ساعت انكوباسيون در دماى rV درجه و

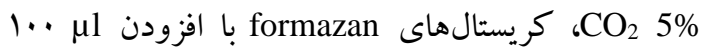
DMSO بهصورت محلول درآمد و ميزان جذب نورى

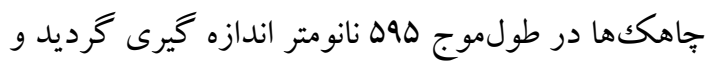
با تعيين نسبت جذب نورى هر نمونه به جذب نورى نمونهٔ كنترل منفى ( viability . ' إدصد)، نسبت بقاى سلولها محاسبه شد (YI) و غلظتى از يّيتيد كه در آن •ه درصد

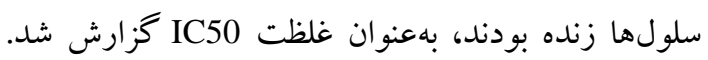

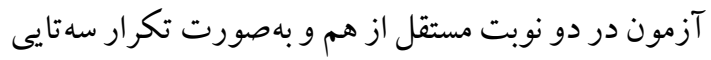
صورت گَفت. با استفاده از درونيابى مقادير MIC براى همة تكرارها تعيين گرديد و آناليزهاى آمارى روى اين مقادير انجام شد. از منحنى Box- Plot براى تشخيص Shapiro- Wilk دادهاى برت (Outlier) و از آزمون

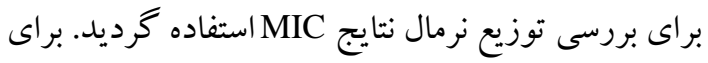

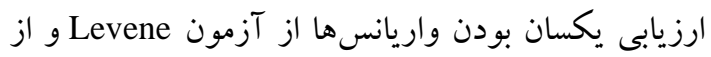

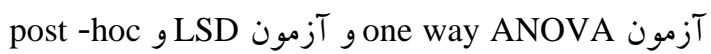
(در شرايط برابرى واريانسها) و آزمون Games-Howell)

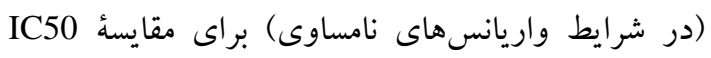
يلى ييتيدهاى موردمطالعه استفاده شد (r) (I).

يافته ها

وسترن بلات براى تأييد بيان بروتئين هدف: با توجه به

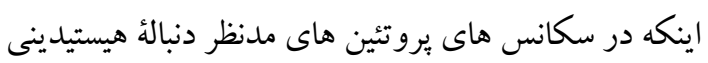

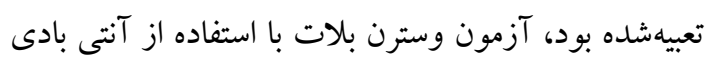
عليه دنبالة هيستيدينى صورت گرفت. تطابق باندهاى مشاهدهشده پِ از مرحلةُ القاى باكترى با باندهاى آزمون
استفاده گرديد. براى ارزيابى يكسان بودن واريانسها از

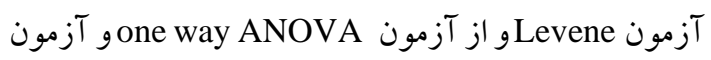
و و (در شرايط برابرى واريانس ها) و post -hoc آزمون Games-Howell (در شرايط واريانس هاى نامساوى) براى مقايسٔ MIC پيلى ييتيدهاى موردمطالعه

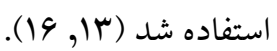
اثرسميت بيتيد بر سلولهاى يوكاريوتى: مطابق استاندارد

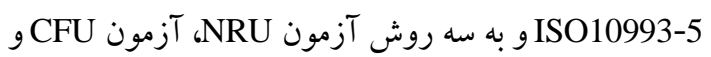
آزمون MTT و آزمون XTT انجام مى گيرد. متداولترين روش در ارزيابى سميت سلولى، سنجش بقاى سلولى به

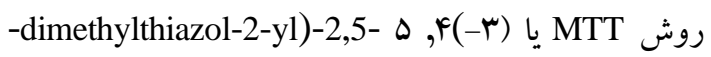
(diphenyltetrazolium bromide MDA-MB-231 (ATCC: HTB-26) انستيتو پاستور ايران تهيه و در فلاسك كشت سلولى ميلى ليتر داراى محيط DMEM حاوى Fetal FBS 10\% 100 u/ml ( حاوى آنتى بيوتيك bovine serum) ينىسيلين و

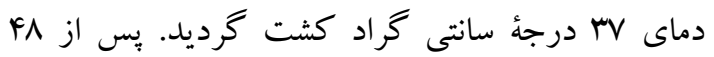

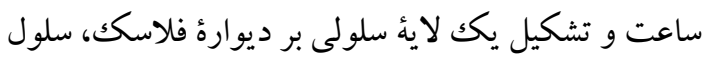

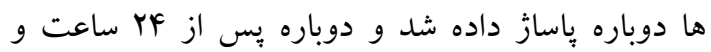
تشكيل تكك لائ سلول ها، بهوسيلة تيمار ملايم با ترييسين از ديواره كنده شد و با سانتريفيوز در دماى F درجهٔ

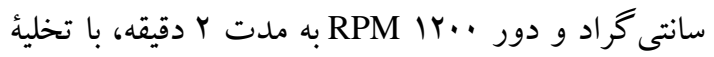

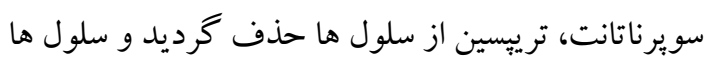
دوباره در محيط كشت بالا حل شد و يس از اطمينان از

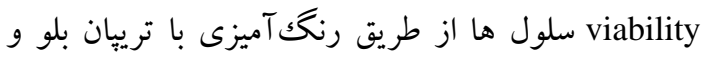

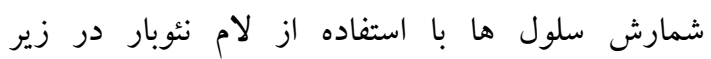

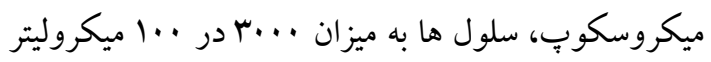

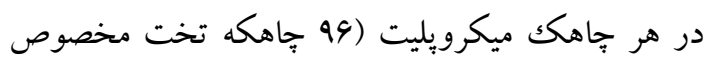

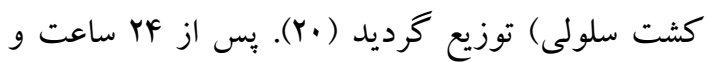

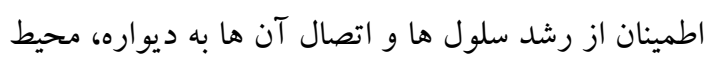

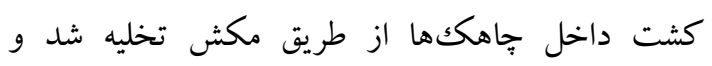

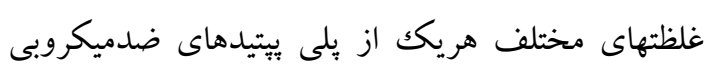

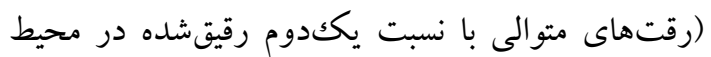


استفاده شد. در همة موارد P value>0.05 و درنتيجه، وسترن، بيان بروتئين هدف را تأييد مى كند (شكل شماره (). توزيع نتايج نرمال بود. با توجه به اينكه در هيجيك از نتايج آزمون MTT آزمون MTT با رده سلولى غلظتهاى آزمون MTT يلى يبتيدها، ميز ان سلولهاى زنده به كمتر از ••ه درصد افت نكرد (IC50)، براى بررسى و مقايسة ميزان سميت ويلىيتيدها، غلظت حداكثر غلظت

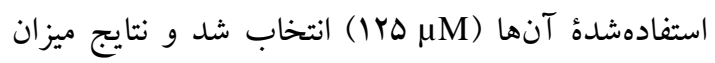
سلولهاى زنده در تماس با اين غلظت از لحاظ آمارى ارزيابى كرديد. براى بررسى معنىدار بودن اختلاف نتايج اين غلظت، از آناليزهاى آمارى با استفاده از نرمافزار كPSS استفاده شد. براى مقايسٔ اثر زمانبر ميزان بقاى سلولى،

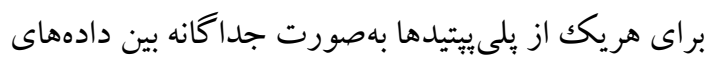

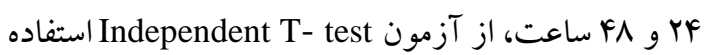
كرديد. P value>0.05 بيانگر معنا دار بودن اختلاف ميز ان سميت توالى هيبريدى با توالىهاى تترامر، S3 و S S3 بود. ميزان بقاى سلولى بس از تماس با هrا ميكرومول از هريك از توالىها در شكل شماره ب نشان دادهشده است. MDA-MB-231 در هريك از ميكرويليتها، ميانخين جذب نورى ردان جاهك هاى بلانكك از جذب نورى هريك از جاهك هـا كسر گرديد. در هر بيليت، ميانگين جذب نورى جاهك هاى كنترل نيز بهعنوان Abs control در نظر كرفته و درصد بقاى سلولى از طريق رابطةٌ زير محاسبه شد:

$\%$ Cell Survival $=\left(\right.$ Abs sample $^{-}$Abs blank $) /($Abs control - Abs blank)*100

شكل شماره Y نشان مىدهد كه در زمان YF و F ساعت، همدُ يبتيدها viability بالاى •ه درصد سلولها را به همر اه داشتهاند كه نشاندهنده خاصيت سميت اندكك اين يَيتيدها در حالت استاندارد و موتانت بر سلولها است. از آزمون شاييرو براى ارزيابى نرمال بودن توزيع نتايج

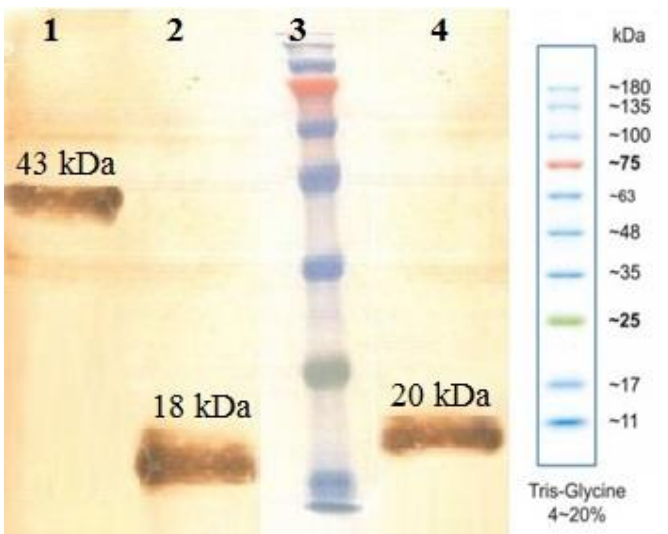

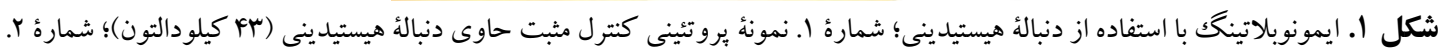

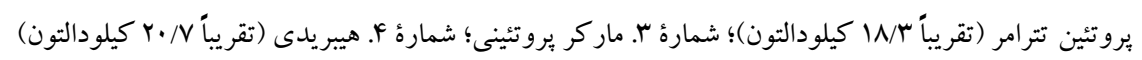
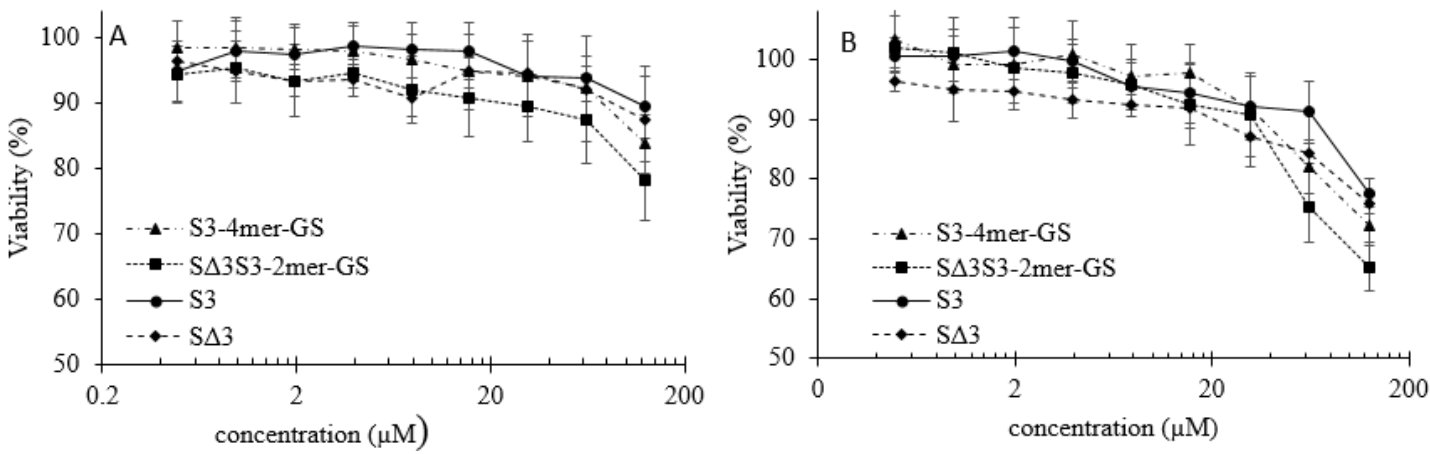

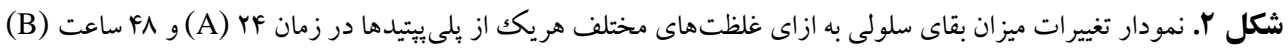




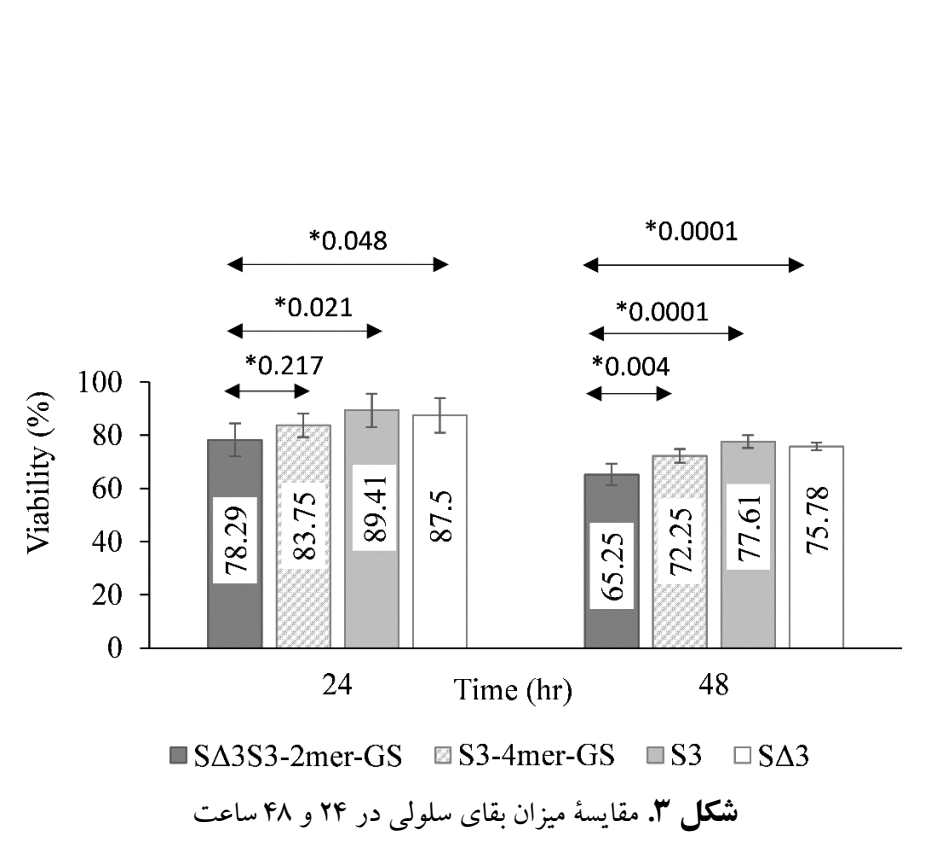

جدول ا. ميزان بقاى سلولى در غلظتهاى فعال ضدميكروبى هريك از توالى ها

\begin{tabular}{lccccc}
\hline AMP & $\mathbf{M w}_{\mathbf{w}}(\mathbf{D a})$ & $\mathbf{M I C}_{\mathbf{G M}}(\boldsymbol{\mu g} / \mathbf{m l})$ & $\mathbf{M I C}_{\mathbf{G M}}(\boldsymbol{\mu M})$ & $\begin{array}{c}\text { Viability } 4 \mathbf{~ h r} \\
(\mathbf{\%})\end{array}$ & $\begin{array}{c}\text { Cytotoxicity } \\
\mathbf{4 8} \mathbf{~ h r}(\boldsymbol{\%})\end{array}$ \\
\hline S $\Delta$ 3S3-2mer-GS & 20680.59 & 47.29 & 2.29 & 98.3 & 1.7 \\
S3-4mer-GS & 20540.23 & 71.84 & 3.5 & 99.2 & 0.8 \\
S3 & 3891.42 & 108.36 & 27.85 & 92.5 & 7.5 \\
S $\Delta 3$ & 3961.5 & 65.59 & 16.56 & 91.4 & 8.6 \\
\hline
\end{tabular}

(ATCC27853 و سوية كلينيكى مقاوم ايزولهشده در

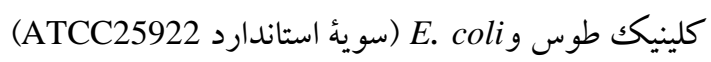
و سوئ كلينيكى مقاوم، بهصورت تكرارهاى جهارتايى ونائي

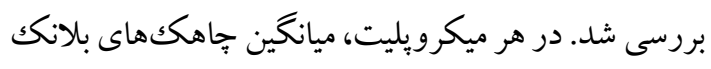

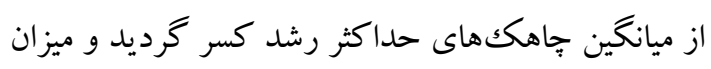
بازدارندگى بر اساس رابطة زير محاسبه شد: Growth Inhibition $(\%)=(\mathrm{OD}$ maximum growth OD sample)/ OD maximum growth *100

منحنى بازدارندگى برحسب غلظت يلى ييتيد رسم

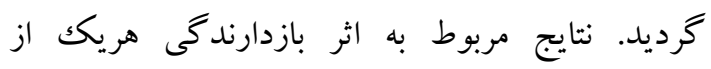
يلى يبتيدها روى سويههاى يادشده در شكل شمارة F آمده

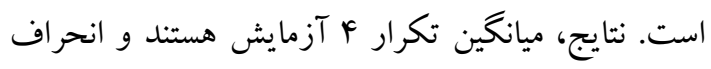

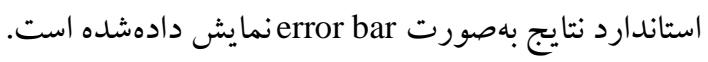

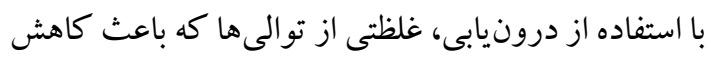

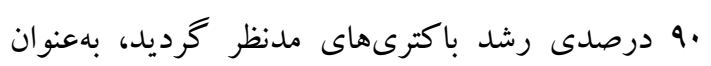
غلظت MIC در نظر كرفته شد.

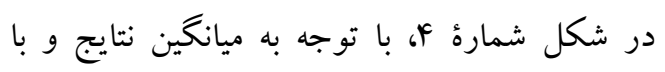

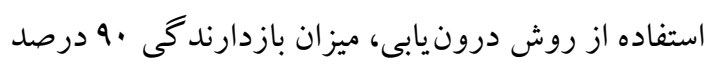

بر اساس شكل شمارهٔ بثابت مى گردد كه در زمان FF

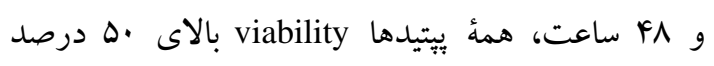

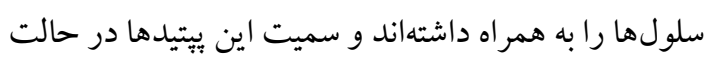
استاندارد و مو تانت بر سلولها يو كاريوت اندك است. از آنجاكه غلظت هr ا ميكرومول بسيار بيشتر از غلظت

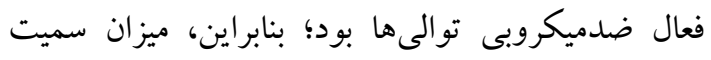

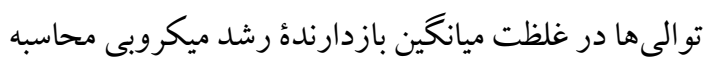

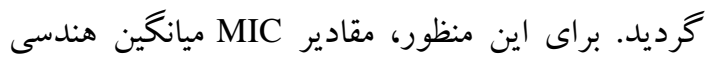
بهدست آمده از مر حلهُ آزمون ضدميكروبى، با استفاده از

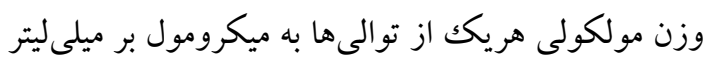

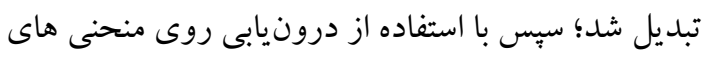
بقاى سلولى، ميزان بقاى سلولى در اين غلظتها محاسبه كرديد (جدول شماره ) (). نتايج آزمون فعاليت ضلدميكروبى: تأثير غلظتهاى مختلف هريكك از توالىهاى هيبريدى، تترامر و يِيتيدهاى

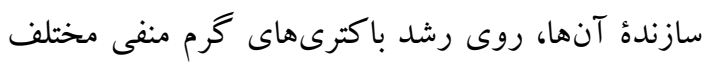
Pseudomonas aeruginosa 
محاسبه گرديد و بهعنوان MIC برحسب Mg/ml در شكل بيانگر اثر مثبت بيان هيبريدى روى فعاليت ضدميكروبى

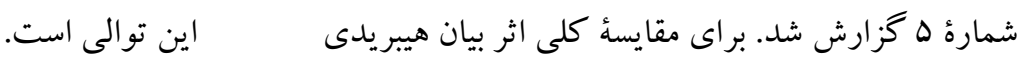

شكل شمارة هاء بيان مى كند كه مو تانت هاى مشتق از

در غلظتهاى يايين ترى، خاصيت ضدميكروبى نسبت به

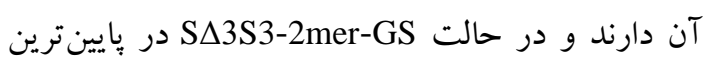

$$
\text { اندازه است. }
$$

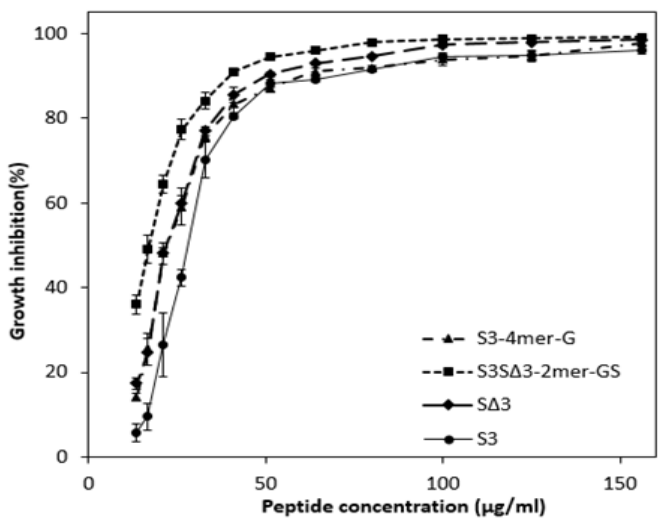

A
از ميانگين هندسى (Geometric mean) استفاده گرديد. بر اساس غلظت ميانكين هندسى، MIC توالى هيبريدى بهترتيب از MIC توالى هاى SA3، تترامر و S3 بهترتيب

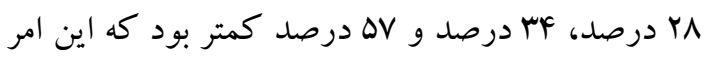

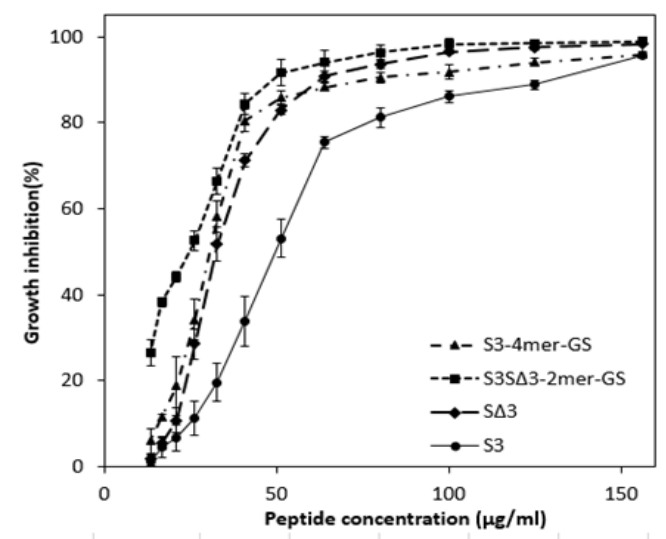

B
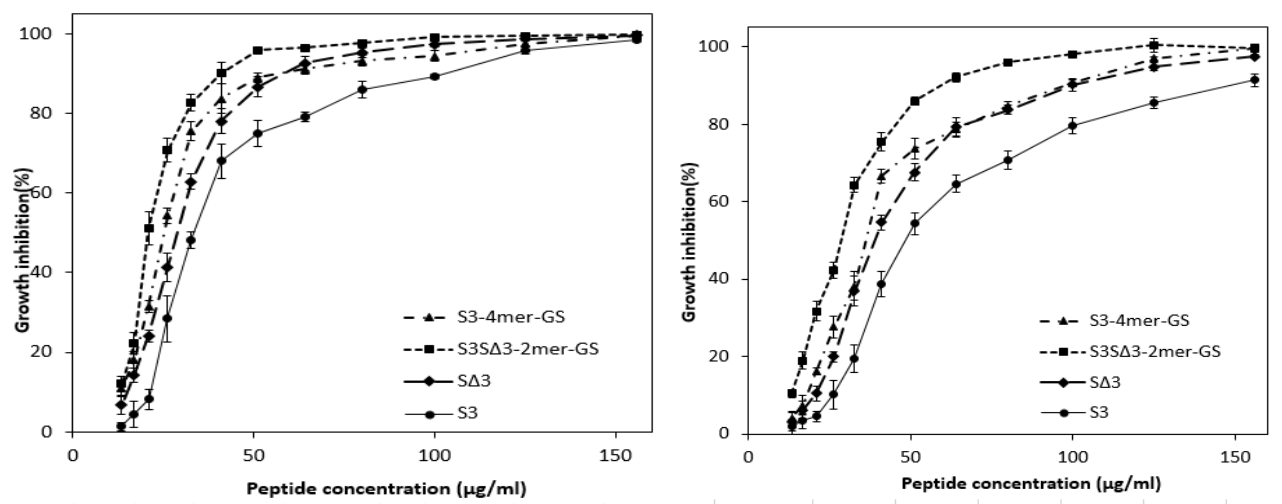

C

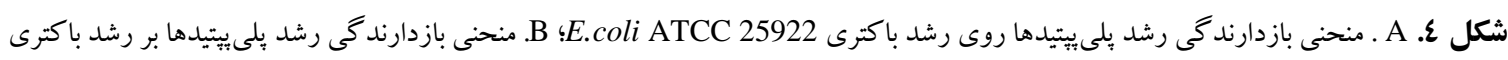
E.coli بازدارندگى رشد بلى يتيدها بر رشد باكترى Pseudomonas aeruginosa كلينيكال مقاوم

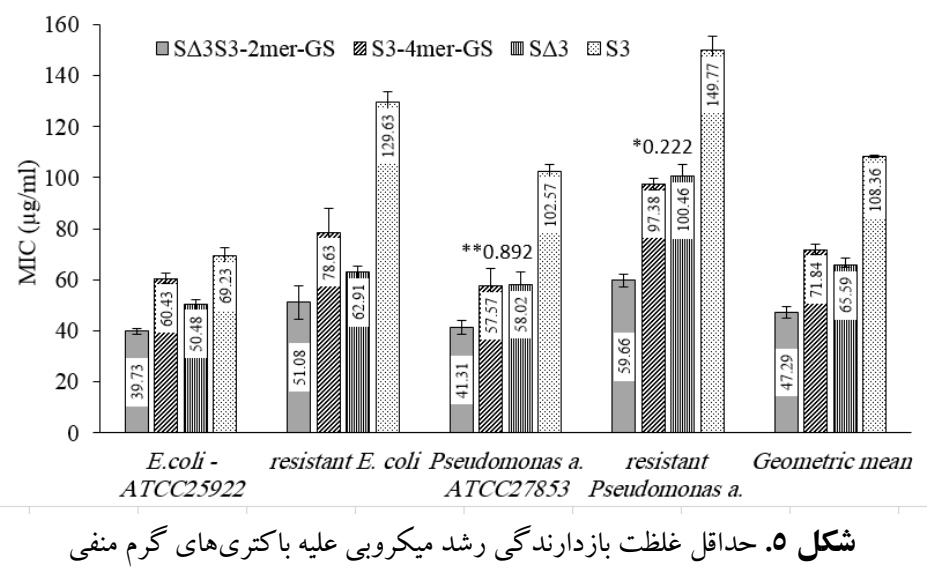




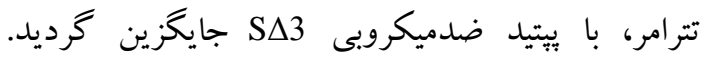

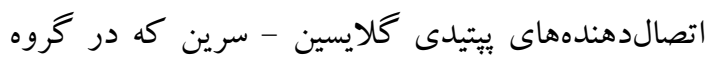
اتصالدهندهاى يّيتيدى منعطف دستهبندى مىشود، فضاى بيشترى را براى عملكرد دمينها در اختيار آنها قرار

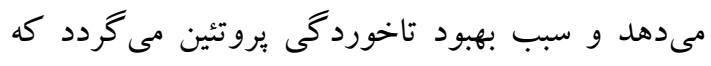

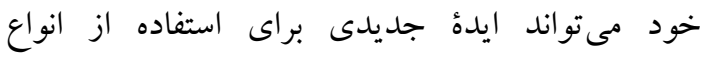
اتصالدهنده و مقايسٔ كارايى آنها در آينده باشد (Yه).

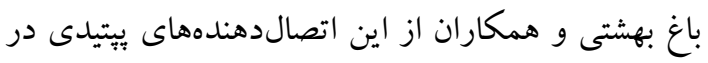

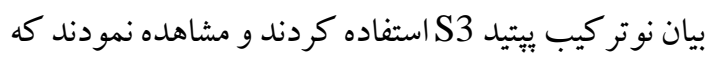
اين لينكر در مقايسه با اتصالدهندههاى يتيتيدى سخت

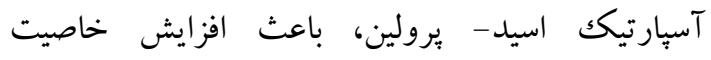

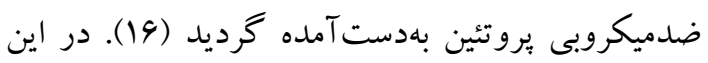

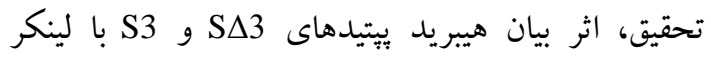
كلايسين سرين مطالعه شد و براى مطالعهُ اثر هيبريداسيون، خاصيت ضدميكروبى و سميت آن با حالت تترامر S3

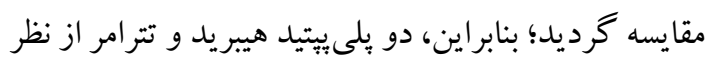

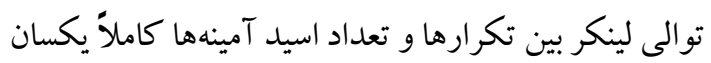
بودند و تفاوتهاى مشاهدهشه در فعاليت بيولوزيكى آنها، صرفاً مربوط به جايخزينى دو يِيتيد S3 با يّيتيد

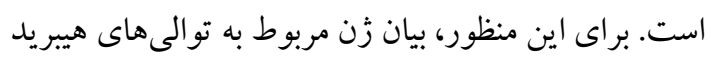

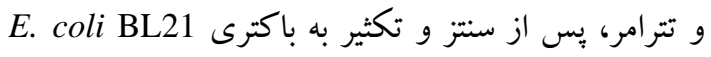

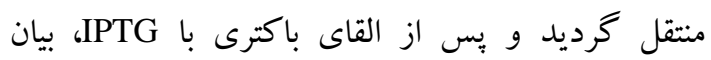

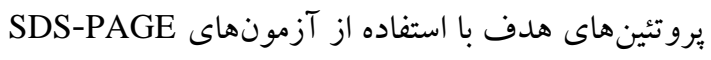
و وسترن (عليه دنبالة هيستيدينى) انجام و بيان آنها تأييد شد. بِ از مرحلة بيان در برخى از كلونهاى بيان كنندة هئه

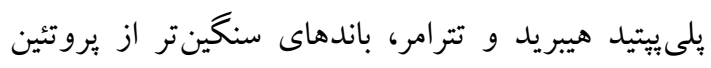
هدف مشاهده گرديد كه با انجام آزمون وسترن، حضور

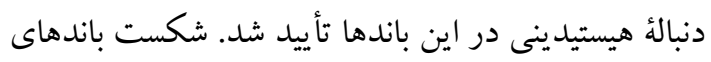

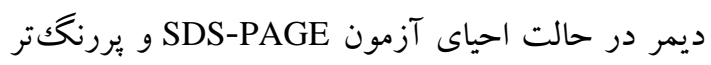

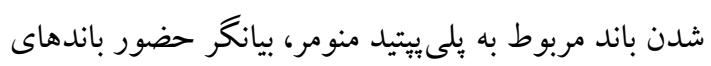

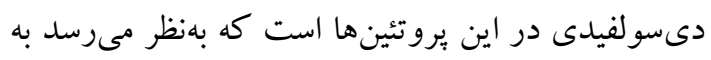

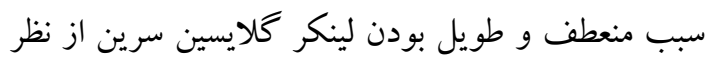

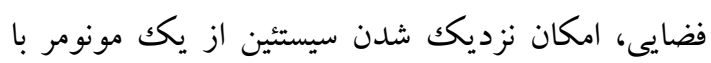
مونومر ديخر و درنتيجه، تشكيل بيوند دىسولفيدى ميان

\section{بحث و نتيجه كيرى}

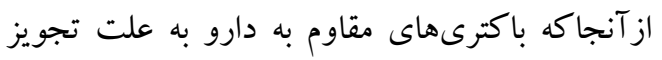

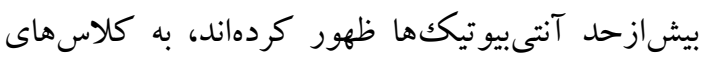

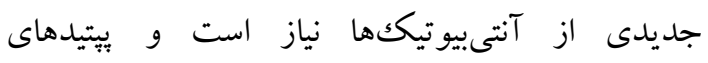
ضدميكروبى با آثار جانبى كمتر و تأثير بالاتر و همجينين

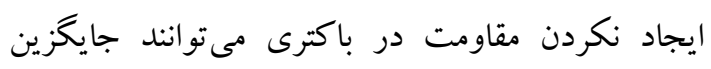

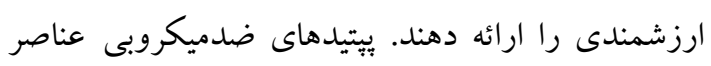
اصلى سيستم ايمنى ذاتى هستند. اين يّيتيدها، پيتيدهاى

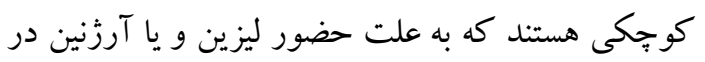
توالى خود، بار مثبت دارند و آمفىياتيك هستند كه عامل فعاليت ضدميكروبى مستقيم اين يتيتيدها است (Y) (Y). غشاى

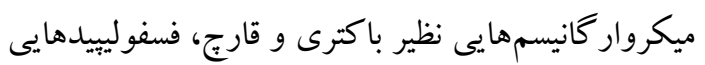
با بار منفى در طرف خارجى غشا دارند كه ييتيدهاى

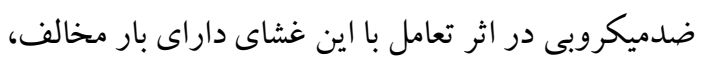

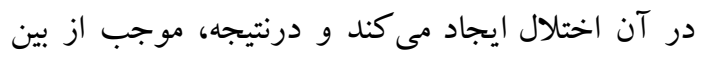

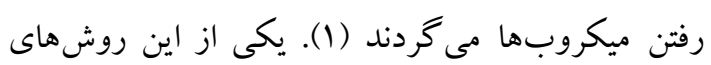

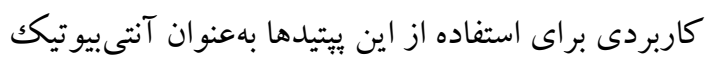
هيبريد و تركيب كردن يتيتدهاى ضدميكروبى با يكديخر

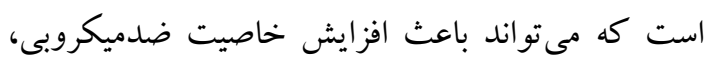

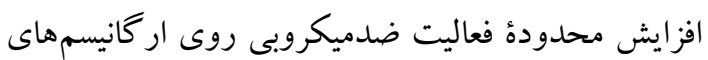

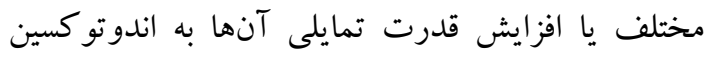

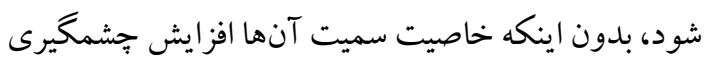

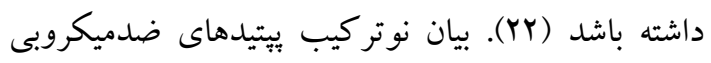
بهصورت مولتىمر يا هيبريد، نوع خاصى از بيان فيوزن است كه امكان دسترسى به مقادير بيشترى از يِيتيدهاى

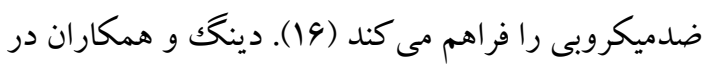

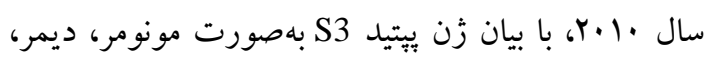

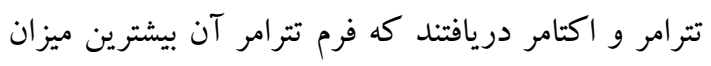

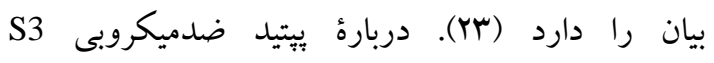
كزارش شده است كه از ميان حالات ديمر، تترامر و اكتامر، بيشترين فعاليت مربوط به فرم تترامر اين ييتيد است (YF).

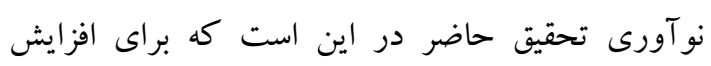

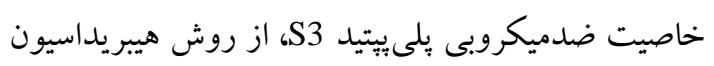
استفاده شد، بهطورى كه دو واحد يِيتيد S3 سازنده فرم 
نيز مشاهده شد. در بيان نوتركيب ييتيدهاى F17 (F) ضدميكروبى اعم از بيان فيوزن يا مولتىمر، بررسى اثر بردي

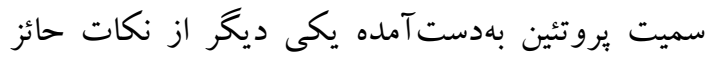

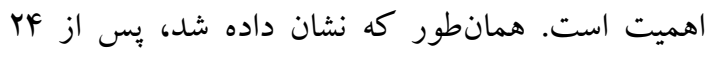
ساعت تماس، ميزان بقاى سلولى در مورد يروتئين هيبريد

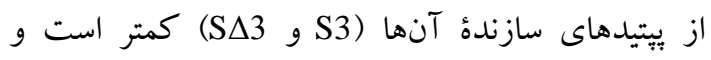

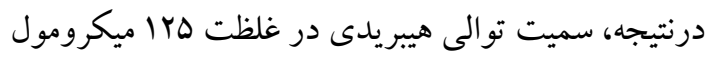

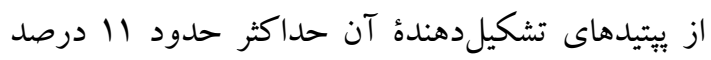
بيشتر است؛ اما اختلاف حدود هـ درصد در مقادير بقاى

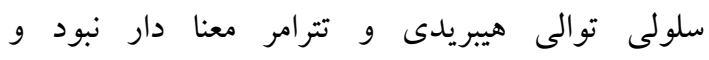

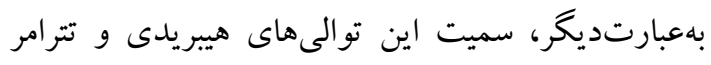

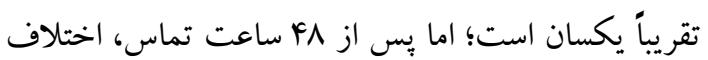
مشاهدهده ميان مقادير بقاى سلولى در مورد توالى هيبريد با توالىهاى تترامر و يِيتيدهاى سازنده معنا دار بود و اين بدين معنى است كه ميزان سميت توالى هيبريدى تقريباً به ترتيب ه، rا و • ل درصد بيشتر از سميت توالى تترامر، S3 و SA3 بود. تنها تفاوت سميت حالت تترامر با منومرهاى سازنده آن (SA3, S) معنىدار بود. همانطور كه نشان داده شد، ميزان بقاى سلولى براى هريكك توالى ها با افزايش زمان، كاهش بيدا مى كرد؛ بنابراين، سميت توالىها به زمان نيز وابسته بود و با افزايش زمان تماس، افزايش مىيافت.

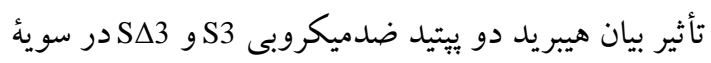
بيان گرديد و با ميزان بيان و فعاليت E.coli BL 21(DE3) بيولوزيكك بروتئين نوتر كيب تترامر S3 مقايسه شد. مقايسٔ

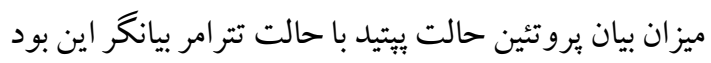
كه افزايش بار مثبت در بروتئين هيبريد، براى باكترى بئيد

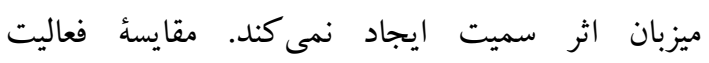

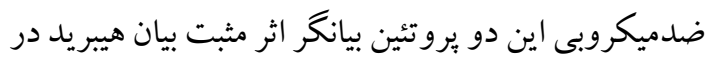

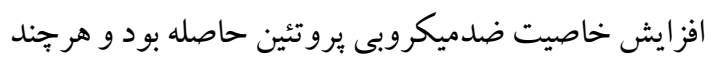

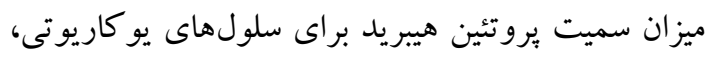

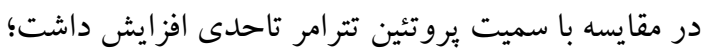

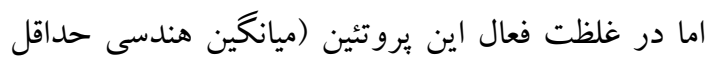

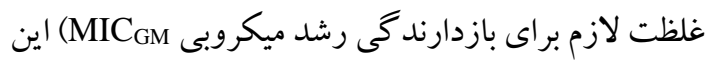

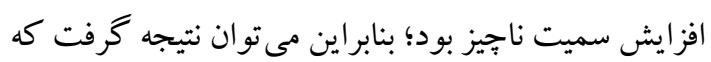

دو مونومر فراهم شده است و بروتئين به حالت ديمر تبديل

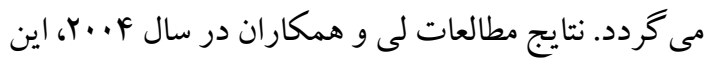

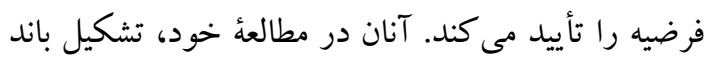
دى سولفيدى ميان مونومرهاى ييتيد S3 و درنتيجه، تشكيل

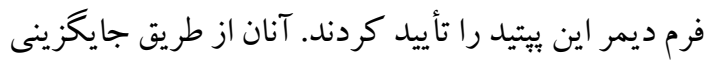

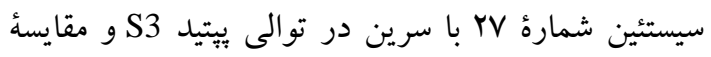
قدرت اتصال موتانت حاصله به LPS دريافتند كه قدرت

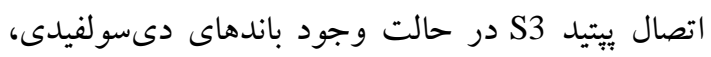

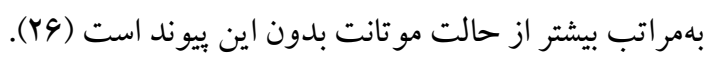
براى بررسى اثر بيان هيبريد يتيدهاى S3 و SA3، ميانكين

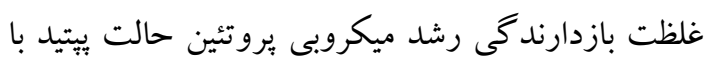
مقدار متناظر آن از يروتئين تترامر S3 مقايسه گرحديد. همانطور كه نشان داده شد، مقدار MIC تو الى هيبريدى از مقادير متناظر مربوط، نسبت به حالت بيان تترامر و يبتيدهاى سازندة آن شامل SA3 و S3 به ترتيب باعث بهبود ه د درصدى بهبو ديافته بود. S S واريانتى از يّتيد

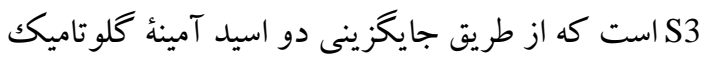

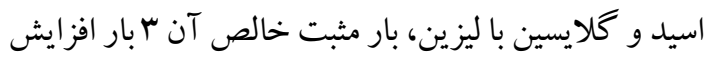
يافته و اين امر باعث بهبود خاصيت اتصال آن به

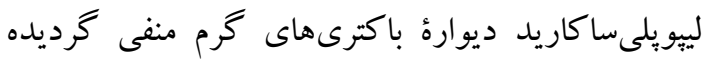
است (YV). در تحقيق حاضر، بيان هيبريد توالى S3 و SA3 باعث افزايش بار مثبت خالص بروتئين حاصله (9+) در

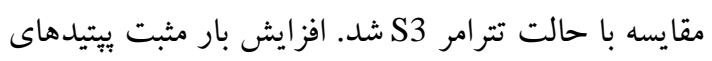

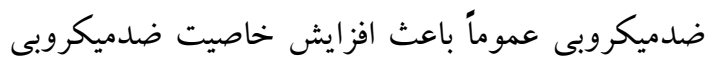

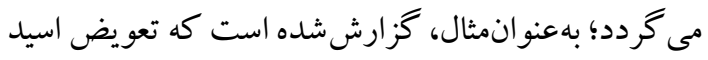
آمينة كلايسين در توالى يبتيد ضدميكروبى alyteserin-2a باعث افزايش خاصيت ضدميكروبى آن گرديد (YN). بهطور مشابه، در واريانت جديدى از يبتيد S3، حذف باصن بار منفى از توالى اين يِيتيد، به افزايش بار مثبت و درنتيجه،

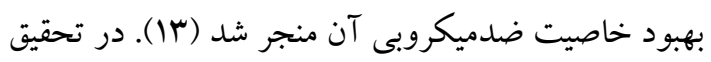

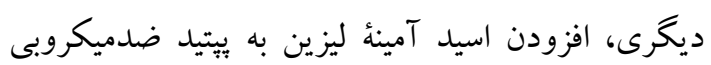

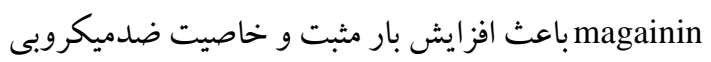
واريانت جديد گرديد (Yq). همين اثر در ساير يبتيدهاى

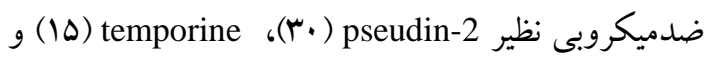




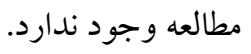

$$
\text { كد اخلاق }
$$$$
\text { نداشت. }
$$

\section{References}

1. Zasloff M. Antimicrobial peptides innate immunity and the normally sterile urinary tract. J Am Soc Nephrol2007; 18:2810-6. doi.10.1681/ASN.2007050611

2. Hancock RE, Sahl HG. Antimicrobial and host defense peptides as new anti infective therapeutic strategies. Nat Biotechnol 2006; 24:1551-7. doi.10.1038/nbt1267

3. Guilhelmelli $\mathrm{F}$, Vilela $\mathrm{N}$, Albuquerque $\mathrm{P}$, Derengowski L, Silva I, Kyaw C. Antibiotic development challenges: the various mechanisms of action of antimicrobial peptides and of bacterial resistance. Front Microbiol2013; 4:353. doi.10.3389/fmicb.2013.00353

4. Kotsianidis I, Kokkinou D, Siapati E, Miltiades P, Lamprianidou E. Identification of a chemoresistant oxidative state low leukemic subpopulation in cd $34^{+}$human acute myeloid leukemia cell cycle analysis sorted subsets were stained with Ki67. J Stem Cell Res Ther 2014;4:9. doi. 10.4172/21577633.100023

5. Li Y. Recombinant production of antimicrobial peptides in Escherichia coli a review. Protein Exp Pur2011; 80:260-7. doi.10.1016/j.pep.2011.08.001

6. Yusupova YR, Skripnikova VS, Kivero AD, Zakataeva NP. Expression and purification of the 5'-nucleotidase YitU from Bacillus species: its enzymatic properties and possible applications in biotechnology. Appl Microbiol Biotechnol2020; 104:2957-72. doi.10.1007/s00253-020-10428-y

7. Rao $X, \mathrm{Hu} J$, Li S, Jin $X$, Zhang $C$, Cong $\mathrm{Y}$, et al. Design and expression of peptide antibiotic hpab- $\beta$ as tandem multimers in Escherichia coli. Peptides2005; 26:721-9. doi. 10.1016/j.peptides.2004.12.016.

8. Leptihn S, Guo L, Frecer V, Ho B, Ding JL, Wohland T. One step at a time: Action mechanism of Sushil antimicrobial peptide and derived molecules. Virulence 2010; 1:42-4. doi.10.4161/viru.1.1.10229

9. Chen X, Zaro JL, Shen WC. Fusion protein linkers property design and functionality. Adv Drug Deliver Rev2013; 65:1357-69. doi.10.1016/j.addr.2012.09.039

10. Lorenzini DM, Silva JR PI, Fogaça AC, Bulet P, Daffre S .Acanthoscurrin: a novel glycine-rich antimicrobial peptide constitutively expressed in the hemocytes of the spider Acanthoscurria gomesiana. Dev Comp Immunol 2003; 27:781-91. doi.10.1016/s0145-305x(03)00058-2

11. Sperstad SV, Haug T, Vasskog T, Stensvag K. Hyastatin a glycine rich multi domain
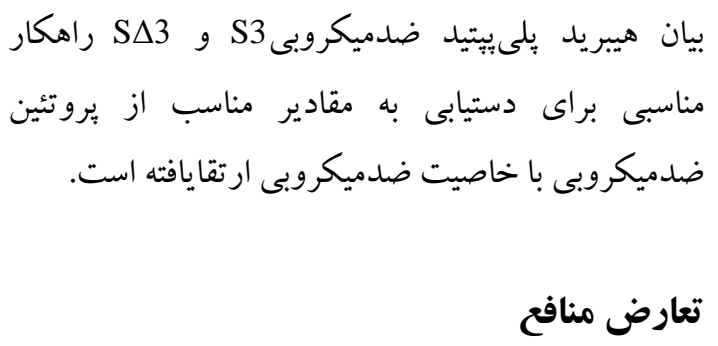

نويسند گان اعلام مى كنند كه تضاد منافعى در اين

antimicrobial peptide isolated from the spider crab hemocytes. Mol Immunol 2009; 46:2604-12. doi.10.1016/j.molimm.2009.05.002

12. Zhang SK, Song JW, Gong F, Li SB, Chang HY, Xie HM, et al. Design of an ahelical antimicrobial peptide with improved cell selective and potent anti biofilm activity. Sci Rep2016; 6:27394. doi. 10.1038/srep27394 2016

13. Sepahi M, Ahangari Cohan R, Hadadian S, Norouzian D. Effect of glutamic acid elimination substitution on the biological activities of S3 cationic amphiphilic peptides. Pre Biochem Biotechnol2020; 50:664-72. doi.10.1080/10826068.2020.1725772

14. Yin LM, Edwards MA, Li J, Yip CM, Deber CM. Roles of hydrophobicity and charge distribution of cationic antimicrobial peptides in peptide membrane interactions. J Biol Chem2012; 287:7738-45. doi.10.1074/jbc.M111.303602

15. Shang D, Li X, Sun Y, Wang C, Sun L, Wei S, et al. Design of potent, non-toxic antimicrobial agents based upon the structure of the frog skin peptide temporin1CEb from Chinese brown frog, Rana chensinensis. Chem Biol Drug Des 2012; 79:65362. doi.10.1111/j.1747-0285.2012.01363.x

16. Baghbeheshti S, Hadadian S, Eidi A, Pishkar L, Rahimi H. Effect of flexible and rigid linkers on biological activity of recombinant tetramer variants of s3 antimicrobial peptide. Int J Pept Res Ther2021; 27:457-62. doi.10.1007/s10989-02010095-7

17. Gasteiger E, Hoogland C, Gattiker A, Wilkins MR, Appel RD, Bairoch A. Protein identification and analysis tools on the ExPASy server. $2^{\text {th }}$ ed. Proteom Prot Handbook Totowa New Jersey Springer Publication. 2005; P. 571-607. doi.10.1385/1-59259-890-0:571.

18. Maboudi K, Hosseini SM, Sepahi M, Yaghoubi H, Hadadian S. Production of erythropoietin specific polyclonal antibodies. Iranian J Biotechnol2017; 15:50. doi. doi.org/10.15171/ijb.1413

19. Wiegand I, Hilpert K, Hancock RE. Agar and broth dilution methods to determine the minimal inhibitory concentration of antimicrobial substances. Nat Prot2008; 3:163-75. doi. 10.1038/nprot.2007.521

20. Burns KE, McCleerey TP, Thevenin D. PH selective cytotoxicity of pHLIP antimicrobial peptide conjugates. Sci Rep2016; 6:28465. doi.10.1038/srep28465

21. Cirac A, Torne M, Badosa E, Montesinos E, Salvador P, Feliu L, et al. Rational design of 
cyclic antimicrobial peptides based on bpc 194 and bpc198. Molecules2017; 22:1054. doi. 10.3390/molecules22071054

22. Almaaytah A, Qaoud MT ,Abualhaijaa A, Albalas Q, Alzoubi KH. Hybridization and antibiotic synergism as a tool for reducing the cytotoxicity of antimicrobial peptides. Inf Drug Res2018; 11:835. doi.10.2147/IDR.S166236

23. Ding JL, Ho B. Endotoxin detection from limulus amebocyte lysate to recombinant factor $\mathrm{c}$ endotoxins structure. Func Rec Springer Publication.2010. P. 187-208. doi. 10.1007/97890-481-9078-2_9.

24. Rezaei S, Hadadian S, Khavarinejad RA, Norouzian D. Recombinant tandem repeated expression of $\mathrm{s} 3$ and $\mathrm{s} \delta 3$ antimicrobial peptides. Rep Biochem Mol Biol 2020; 9:348. doi. 10.29252/rbmb.9.3.348

25. Sabourin M, Tuzon CT, Fisher TS, Zakian VA. A flexible protein linker improves the function of epitope tagged proteins in Saccharomyces cerevisiae. Yeast 2007; 24:39-45. doi. 10.1002/yea.1431

26. Li P, Wohland T, Ho B, Ding JL. Perturbation of lipopolysaccharide micelles by sushi 3 antimicrobial peptide the importance of an intermolecular disulfide bond in s3 dimer for binding, disruption, and neutralization of lps. J Biol Chem2004; 279:50150-6. doi 10.1074/jbc.M405606200

27. Yau YH, Ho B, Tan NS, Ng ML, Ding JL. High therapeutic index of factor C Sushi peptides: potent antimicrobials against Pseudomonas aeruginosa. Antimicrob Age Chemother 2001; 45:2820-5. doi.10.1128/AAC.45.10.2820-2825.2001

28. Conlon JM, Mechkarska M, Arafat K, Attoub S, Sonnevend A. Analogues of the frog skin peptide alyteserin-2a with enhanced antimicrobial activities against Gram-negative bacteria. J Pept Sci 2012; 18:270-5. doi.10.1002/psc.2397

29. Dathe M, Nikolenko H, Meyer J, Beyermann M, Bienert M. Optimization of the antimicrobial activity of magainin peptides by modification of charge. FEBS Lett 2001; 501:146-50. doi. 10.1016/S0014-5793(01)02648-5

30. Pal T, Sonnevend A, Galadari S, Conlon JM Design of potent, non toxic antimicrobial agents based upon the structure of the frog skin peptide pseudin2. Regul Pept 2005; 12 :85-91. doi. 10.1016/j.regpep.2005.01.015 